\title{
分割画像ごとの相関法による空中写真からの自動図化
}

\section{Stereo Plotting from Aerial Photographs with Patch by Patch Correlation}

\author{
森 忠次* ·服部 進* · 内田 修** \\ Chuji Mori, Susumu Hattori, Osamu Uchida
}

\begin{abstract}
This paper proposes a patch by patch correlation method for automatic stereo plotting from aerial photographs for the control of matching wanderings, where matching is made on all over a fairly large patch area rather than at every each point. Its effectiveness is evidenced in the experiments.

The structure of the algorithm is as follows;

1) A stereo image pair is subdevided to overlapping patch pairs, each consisting of about 250 by 250 pixels and 250 by 400 pixels for the left and right patches respectively. Matching process is done independently for each patch pair. 2) The grid points are allocated on the left patch and their conjugates are searched. At the start matchings are done coarsely using low frequency components of the images, converged step by step to fine details using high frequency components. In accordance with this coarse-to-fine process the grid points are disposed sparcely at the first step and their density is increased step by step.

3) It is essential in this method to pose the positional constraint on the matched points to keep the geometrical consistency.

4) Phase distortions of the images due to terrain reliefs are eliminated by iterative correlation.

要 旨：この論文は空中写真対のステレオマッチングで, マッチングの迷走を防ぐ手段としてパッチ単位ごとのマッ チングを提案し，それが有効であることを実験で示した。アルゴリズムの主たる構造は次のようである。

(1) 図化領域の左画像を約 $250 \times 250$ 画素，右画像を約 $250 \times 400$ 画素の重複するパッチにわけ，マッチングは各パッ チで独立に実行する。

(2) 左パッチに格子点をとり, その右画像上の対応点を探索するが, 最初低周波域の粗いマッチングから始め, 高周波域 の細かいマッチングに収束させる 3 段階の過程をとる。格子点密度も最初は疎にし，しだいに密に配置する。

（3）対応点は位置の整合性を満たすよう制約条件を付け，探索幅を狭めると同時に迷走を防ぐ。

（4）相関を低下させる位相歪はくり返し相関によって除いていく。
\end{abstract}

\section{1. 緒言}

計算機の処理能力が高くなった近年では，ステレオ マッチングを計算機でシミュレーションし, 実体写真 測量の自動化を実用にしようとするようになってきた。 実体視の機構自体の研究は, 心理物理学や生理学の分 野でなされていて近年その成果を数学的にモデル化す

* 岡山大学

** アジア航測㑣

「写真測量とリモートセンシング」Vol. 24, №. 1， 1985
ることが, 人工知能の開発の 1 つの重要なテーマとし て進められてている。1), 2), 3),4)一方, 写真測量学の分野 では,より実用的な考えから, 実体視のシミュレーシ ヨンというよりも, 面積相関による類似性の探索に基

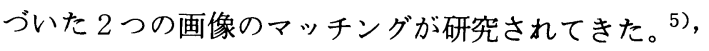
6), 7), 8) 面積相関では 1 つの面像上の点の対応点を見出 すのに, この点のまわりに相関空をとって前者を後者 の中で動かし, 最大相関点を見出そうとするものであ る。これまでに開発されたいわゆる自動図化機は, 例 外なく面積相関法によっている。この方法では相関空 の大きさが精度を決定するため, 提案されたシステム 


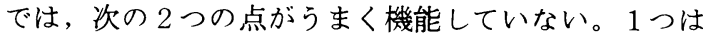
視準方向の違いによるいわゆる隠蔽 (occlusion) の部分 で正しいマッチングができないこと。他の 1 つは，水 面, 草地などのテクスチャの乏しい場所でマッチング が迷走してしまうことである。この論文は主として後 者に対する改良法を提示したものである。これまでの 大多数の方法では, 左画像上においた画像点の対応点 をマッチングするのに各画像点の相対的位置を考慮に 入れないでいわば各点ごとに行っていた。著者はこの 点を改良することによりマッチングの迷走を防ぐこと ができると考えた。9)，10）著者は左右画像をいくつかの 処理単位 (パッチと呼ぶ)の対に分け, 左画像のパッチ 上に設置した正方格子の格子点の対応点を位置の整合 性を考慮しながらマッチングさせる方法をとったとこ ろ良好な結果を得ることができた。この報文はアルゴ リズムの概要を紹介し，これによるいくつかの実駼結 果を示した。

\section{2. パッチごとの相関法の構造}

相関空の大きさ以上の解像力で対応点を決定するこ とはできないから，相関空はできるだけ小さくするの が精度上好ましい。ところが小さな相関空では空内の テクスチャが不足して探索の迷走が起こり易くなる。

迷走を起こさないマッチングと精度良いマッチング という要求は, 相関空の大きさ決定に対する相反する 要求であり, 1 回の相関手続きで満足な結果を得るこ とはむつかしい。これを解決するのに，著者は最初低 周波域で粗いマッチングを行い，しだいに高周波での 細かいマッチングに移る段階的過程が有効であること


の歪は相関を低下させるとしても，この影響が比較的 少ない低周波域を迷走を防ぐとともに探索幅を狭める のに使い，その後に高周波域で細部のマッチングを行 う。

一般にある段階の画像の画素幅を $S$ として, $\ell \times \ell$ 画素の相関空を考える。相関空の幅は, $L=S \ell$ であ る。面積相関ではお㧍むね $1 / 2 S \sim 1 / 2 L$ の周波数帯 を利用することになる。もとのデジタル画像の画素 幅を $s$ で表わすと, 著者は, 最初 $S=4 s$ の画素幅の 画像で相関をとり，次に $2 s ， s$ と半分ずつ 3 段階に 画素幅を小さくする過程をとった。相関空の幅の画素 数とは一定とする。これは, 相関に用いる帯域を 1 オ
クターブずつ高めていくことを意味する。このとき $\ell$ の大小がやはりマッチングの精度と安定性を左右する

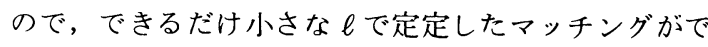
きるように緒言で述べたパッチごとのマッチングを考 案して良好な結果を得た。

面積相関では，地形起伏による投影の歪が相関を弱 める。このため大きな相関空から小さな相関空へ移る 3 段階の各段階で，1度マッチングした結果得られた 対応点の位置を参照して，投影歪を消去するように右 画像を再サンプリングする。次の相関は，この再サン プリング画像を使い，しだいに相関を高める手法をと った。この過程は対応点が収束するまで続ける。これ をここではくり返し相関と呼ぶことにする。くり返し 相関の有効性もすでに文献(10)で示した。

以上の方法は, 現在のところ, 最も秀れた自動図化 機である Gestalt Photomapper ${ }^{12)}$ も採用されている手 続きに比較的近いものになっていると思われるが，同 製品のマッチングアルゴリズムが詳しく発表されてい ないため比較ができない。

隠蔽部分の処理については，ここでは取り扱ってい ない。そのため, ここで述べる手続きは，建築物や樹 木などの比高の急変部分があまり問題にならない宿尺 1：20,000以下の中小縮尺画像を対象にしている。

\section{3. アルゴリズムの解説}

マッチングのアルゴリズムは，準備の段階である前 処理の部分, 相関計算の部分, および迷走の防止の部 分の 3 つに分けられる。

3-1 マッチングのための前処理

(1) 画像の偏位修正一一相互および対地標定を終えた 写真対に対し, 図一1のように撮影基線に平行なモデ ル平面 $x y$ および $u v$ 上に再投影し, 画像の $y$ 一視差 を消去し， 1 次元マッチングを可能にしておく。

(2) パッチへの分割—マッチング処理は一定の大 きさのパッチごとに独立に行う。図化領域の原画像 対を複数のパッチに分割し，左パッチは $255 \times 255$ 画 素, 右パッチは $255 \times 400$ 画素の大きさにとる。隣接 するパッチどおしは 160 画素ずつずらして配置する。 右パッチは, 左パッチよりもu方向に大きくとって探 索幅の余裕をもたせた。これを図一 2 に示すが，図は 便宜上少しずつパッチをずらして描いた。パッチの大 きさや，重複の大きさは(4)で示す格子点配置から決ま 


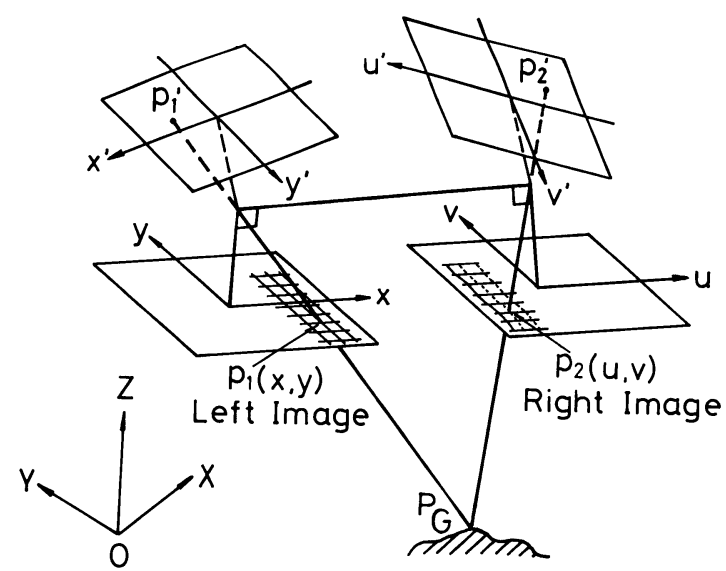

図一 1 偏位修正

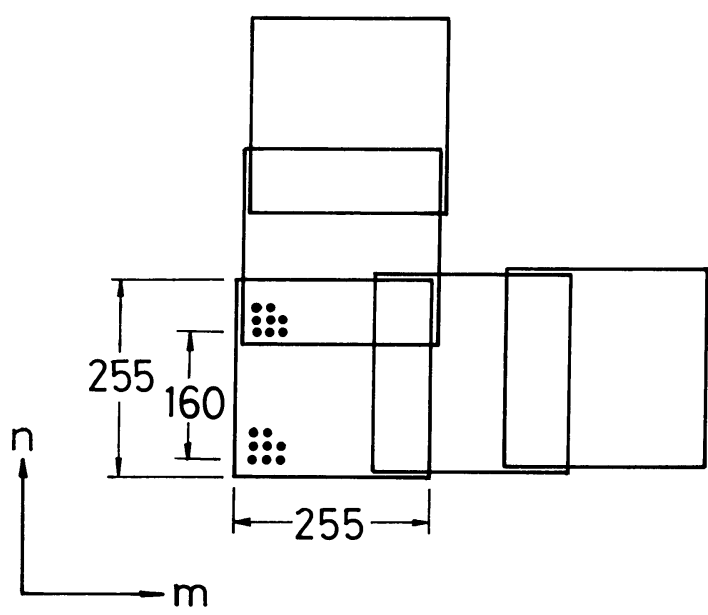

図ー2 重複する左画像上のパッチ (数字の単位は画素)

る。

（3）パッチのフィルタリングー低周波から高周波に 移る各段階の処理でパッチをあらかじめ低域通過フィ ルタに通しておくのが便利である。左または右のパッ 千の画像を総称的に $I_{0}$ で表わす。パッチ $I_{0}$ に低域通 過フィルタを通した画像を $I_{1}, I_{2}$ で表わし,それに含 まれる最高周波数を $f_{c 1}, f_{c 2}$ とする。 $I_{0}$ の最高周波 数は $f_{c 0}=1 / 2$ ( 1 /画素) であるから， $I_{1}, I_{2}$ の力 ット周波数の位置を 1 オクターブずつ下げて, $f_{c 1}=$ $1 / 4, f_{c 2}=1 / 8$ とする。

パッチ $I_{1}, I_{2}$ と $I_{0}$ の間に位相のずれが起こらぬよ う次のようなフィルタを作る。 $I_{0}$ の画像座標系を $m n$ として, これに対する周波数域の座標系を $f_{x} f_{y}$ で表わ す。カット周波数 $f_{c k}=1 / 2^{k+1}(k=1,2)$ の理想低
域通過フィルタを $H_{L k}\left(f_{x}, f_{y}\right)$ で表わすと，

$$
\begin{gathered}
H_{L k}\left(f_{x}, f_{y}\right)=1 \\
\left(\left|f_{x}\right| \leqq \frac{1}{2^{k+1}} \text { かつ }\left|f_{y}\right| \leqq 1 / 2^{k+1}\right. \\
=0 \\
\text { (その他) }
\end{gathered}
$$

となる。 $H_{L k}\left(f_{x}, f_{y}\right)$ をフリェ変換して, フィルタ

$$
\begin{aligned}
& h_{L k}(m, n)=\alpha^{2} \frac{\sin \alpha m \pi}{\alpha m \pi} \cdot \frac{\sin \alpha n \pi}{\alpha n \pi}\left(\alpha=1 / 2^{k} ;\right. \\
& k=1,2)
\end{aligned}
$$

を得る。このフィルターは有限長でないので次の Hanning 空 ${ }^{13)}$

$$
\begin{aligned}
& h_{H k}(m, n)=(0.5+0.5 \cos (\alpha m \pi)) \cdot \\
& (0.5+0.5 \cos (\alpha n \pi)(k=1,2 ; m, n= \\
& \left.0, \pm 1, \cdots \pm 2^{k}\right)
\end{aligned}
$$

を掛けて有限長フィルタ $h_{k}(m, n)$ にする。すなおち

$$
\begin{aligned}
& h_{k}(m, n)=h_{L k}(m, n) h_{H k}(m, n) \\
& \left(k=1,2 ; m, n=0, \pm 1, \cdots \cdots, \pm 2^{k}\right)
\end{aligned}
$$

このフィルタを表一 1 に示した。

実際の処理では画像の標本化定理 ${ }^{14)}$ から, メモリを 節約するため, パッチ $I_{0}, I_{1}, I_{2}$ は含まれる周波数帯 域に応じて画素幅 $S$ の画像をそれぞれ，1，2，4 画 素ごとにサンプリングして縮約したパッチを使った。 すなわち $I_{0}, I_{1}, I_{2}$ の画素幅をそれぞれ $S_{0}=s, S_{1}=$ $2 s, S_{2}=4 s$ によってることになる。今後縮尺した パッチと言えばその画素幅は上の値である。

(4) 格子点の設定一第 3 段階のパッチ $I_{0}$ の右パッチ 上に 8 画素間隔の格子点をつくり，これらを(左) 格子 点と呼ぶ。各格子点に対応する右パッチ上の点を(右) 対応点と呼び, 右対応点の位置を定めるのが眼目であ る。また縮約したパッチ $I_{1}, I_{2}$ 上にも 8 画素間隔で格

$$
\begin{array}{ccc} 
& \text { 表一 } 1 & \text { 低域通過フィルタ } \\
h_{1}(m, n) & \\
0.038 & 0.119 & 0.038 \\
0.119 & 0.373 & 0.119 \\
0.038 & 0.119 & 0.038
\end{array}
$$

$$
h_{2}(m, n)
$$

$\begin{array}{lllllll}0.000 & 0.001 & 0.003 & 0.004 & 0.003 & 0.001 & 0.000 \\ 0.001 & 0.010 & 0.023 & 0.030 & 0.023 & 0.010 & 0.001 \\ 0.003 & 0.023 & 0.056 & 0.072 & 0.056 & 0.023 & 0.003 \\ 0.004 & 0.030 & 0.072 & 0.094 & 0.072 & 0.030 & 0.004 \\ 0.003 & 0.023 & 0.056 & 0.072 & 0.056 & 0.023 & 0.003 \\ 0.001 & 0.010 & 0.023 & 0.030 & 0.023 & 0.010 & 0.001 \\ 0.000 & 0.001 & 0.003 & 0.004 & 0.003 & 0.001 & 0.000\end{array}$




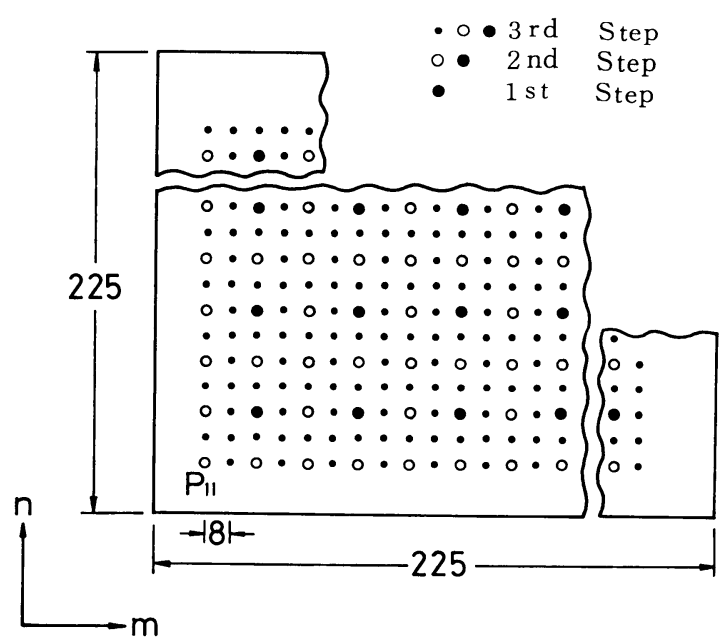

図一3 左パッチ上の格子点配置

（数字の単位は画素）

子点を置きこれらの格子点はパッチ $I_{0}$ 上で考えたとき 図ー3のように重なるようにする。図一 3 では格パッ チの格子点を記号を変えて示した。図の数字単位は画 素（画素幅は $S=s$ ) である。格子点数はパッチ $I_{0}$, $I_{1}, I_{2}$ に対して $24 \times 24,12 \times 12,6 \times 6$ である。? ッチング終了後には， $I_{0}$ 上の格子点の対応点が決定 されるが，外周の対応点は信頼性が低いと判断して捨 て, 内側の $20 \times 20$ 点を図化に使用する。格子点番号を $I_{0}$ 上の格子点に付け, $\mathrm{P}_{i j}$ で表わす。 $m$ 方向に $i, n$ 方向 に $j$ とり, 左下すみの点を $\mathrm{P}_{11}$ とする。

$3-2$ 相関の計算

最初はパッチ対 $I_{2}$ をマッチングさせる。その結果得 られた格子点の $x$ 一視差を次の段階であるパッチ $I_{1}$ の 格子点に初期值として与える。計測されていない格子 点の $x$ 一視差は内挿して与えることになる。次にパッ チ $I_{1}$ をマッチングさせる。この手続きをパッチ対 $\mathrm{I}_{0}$ ま で段階を追って行い，しだいに細部のマッチングに収 束させる。相関の手続きは各段階でほぼ共通であるか ら, 第 3 段階のパッチ対 $I_{0}$ に関して説明する。

(1) $x$-視差の初期值の設定一第 2 段階のマッチン グの結果確定した格子点 $\mathrm{P} i j$ の右画像の $x$-視差（図 -3 の O印 $)(i, j=1,3,5,7,23)$ 吅第 3 段 階の格子点の $x$ 一視差は次の順序で内挿する。

- $i, j=2,4,6 \cdots, 22$ の格子点を対角 4 点の平均值 で与える。

- $i=3,5,7, \cdots, 23 ; j=2,4,6, \cdots, 22$ の格子点 の $x$-視差および $i=2,4,6, \cdots, 22 ; j=3,5,7$ ， $\cdots, 23$ の格子点の $x$ 一視差を綐横 4 点の平均値として
与える。

-格子点 $(i=2,4, \cdots, 22 ; j=1,23),(i=1$, $23 ; j=2,4, \cdots, 22)$ については近傍の 3 点の $x-$ 視差を平均し, 周辺部は内側の $x$ 一視差に等しくおく。 な㧍第 1 段階から，第 2 段階に移るときの初期值設 定もこれに準ずる。

（2）右画像の再サンプリング—格子点の $x$ 一視差を 参照して右画像を再サンプリングし, 左右画像間の位 相歪を除去する。再サンプリング後の右画像では対応 点は正方格子となる。

(3) 左右画像の相関一相関空と探索空を設定し相関 をとる。相関空の巾 $\ell$ 画素は格子間の相互位置関係を 保ちやすくするために， 2 格子間隔をとり $\ell=15$ とし た。 $\ell=15$ は約 4 オクターブの周波数帯を含むことに なり，これまでに発表されている面積相関の相関空と しては極めて小さい。実験ではこれと寸法の異った相 関空を使った場合との比較を示す。

適当な探索空の大きさ，すなわち探索範囲 $K$ は第 2 段階でどの程度対応点位置が確定されているかに依存 する。すし第 2 段階で迷走が起っていないとしても第 2 段階では $f_{c 1}=1 / 4$ 以上の高周波を含んでいないの で, \pm 1 画素の不確定性がある。しかしもっと一般に 安全側に考え第 2 段階の相関空に含まれる成分の最大 波長 $\lambda=2 \ell の ~ 25 \%$ 程度の位相歪は残っているとみな すと $K=2 \times 15 \times 0.25 \fallingdotseq 7$ 画素程度の探索幅を設定 寸べきである。ここでは第 1 段階の最初を除いて, 各 段階とも縮約したパッチ上で $K=7$ 画素とした。

(4)相関の計算一 一画像間の類似度の尺度としては, (1) 相関係数, (2)濃度差の 2 乗和, (3)偏差積和などが通常 使われる。探索空が大きいときには, 探索空内の濃度 変動が大きいため, 局所的に正規化する相関係数が精 度良い尺度になるが，ここでは探索空を小さくしぼる ことができるため, どれをとっても大差はない。著者 は偏差積和から計算した相関倸数の近似值を使った。

計算法は $x$ 軸方向 1 次元的に示せば充分である。 $x$ 軸方向の濃度值列を左右それぞれ $a_{j}, b_{j}(j=0,1,2$ …）で表わし， $a_{o}, b_{0}$ が当該格子点の相関空および探 索空の先頭に来るよう座標原点をとる。このとき偏差 積和 $S_{k}$ と相関係数 $\rho_{k}(k$ は位置遅れ）は次式で定義す る。

$$
\left.S_{k}=\sum_{j=0}^{\ell-1} \Delta a_{j} \Delta b_{j+k} ; \rho_{k}=S_{k} /\left(\sum_{j=0}^{\ell-1} \Delta a_{j} 2\right)\right)
$$




$$
\left.\begin{array}{l}
\Delta a_{j}=a_{j}-\frac{1}{\ell} \sum_{j^{\prime}=0}^{\ell-1} a_{j^{\prime}} ; \Delta b_{j}=b_{j}-\frac{1}{\ell+K-1} \\
\ell+\sum_{j^{\prime}=0}^{\ell-2} b_{j^{\prime}}
\end{array}\right\} \text { (5) }
$$

（5）くり返し相関—相関を低下させる位相の歪を除 去し，相関を向上させるために，(2)で述べたのと同様 に相関と再サンプリングの手続きを $x$ 一視差の值が収 束するまでくり返す。計測した格子点の $x$ 一視差には 微小な震動が含まれていて，このまま再サンプリング するとかえって相関の低下を招くことが多く，マッチ ングはしばしば迷走した。これを防ぐために再サンプリ ングの前の各格子点 $\mathrm{P}_{1 i}$; の $x$ 一視差を, 自らを含む, 縦横 5 点の $x$-視差の平均值に置きかえるフィル夕操 作が有効であった。

\section{$3-3$ 迷走の防止}

マッチングの迷走を防ぐをめに, 著者は以下の 4 つ の方法を試みた。今のところ充分な効果を得ているの は(1)のみである。

（1）対応点の整合性——対応点同志は位置的に矛盾の ない整合性を満足しなければならないが相関空が小さ くなるにしたがって，対応点の整合性がくずれ易くな る。実験によれば一旦整合性がくずれると，くり返し 相関の過程でマッチングが発散することが多かった。 迷走防止のために次の $2 つ の$ 整合性を検査して, 条件 に触れた格子点の $x$ 一視差は周囲の格子点の $x$ 一視差 の平均值とおきかえた。

- 右対応点は, 左格子点と $x$ 軸方向に同じ順序で並ん でいなければならない。

・格子点間の地形勾配が予想される最大勾配以下 ${ }^{15)}$ あること。この論文では 45 以下とした。したがって探 索幅もこれを満たすように設置すれば最大が格子間隔, すなわち縮約された画像で士 8 画素内といらことが導 かれる ${ }^{11)}$

(2) エッジの検出一一各格子点に設定した相関空に必 要なテクスチャが含まれているかどうかを判断するに は, 通常空内濃度値の分散を用いているが, 分散の大 小とマッチングの可能性とは直接結びつかない。ここ では, 各段階のパッチの格子点近傍にエッジが存在す るか否かでこれを判断した。エッジが存在しなければ 格子点近傍は均質な画像であり地形も等勾配であると 判断し, 周囲の格子点の $x$ 一視差を内挿する。近傍の 大きさは, 各段階の格子間隔にほぼ等しくとり縮約し
た画像上土 3 画素とした。マッチングには，y軸方向 のエッジだけが寄与寸るであろらから $x$ 方向の 2 階微 分の零交差点が存在するかでエッジを検出した。すな わち, 縮約した左パッチの画像座標 $(m, n)$ の濃度值 を, $D(m, n)$ としたとき，

$$
G(m, n)=D(m+1, n)-2 D(m, n)
$$$$
+D(m-1, n) \cdots
$$
が あるいは

$$
G(m+1, n) G(m, n)<0,|G(m, n)| \geqq 1.0
$$$$
G(m+1, n) G(m, n)<0, \quad|G(m, n)|<1.0
$$

であれば $(m, n)$ でエッジが存在するとした。 $4-1$ で 示すように濃度值はもともと整数值で与えられている から $|G(m, n)|<1.0$ は=0 とみなしている。

実際には, 実験に用いた画像ではどの段階において も全ての格子点近傍でエッジが存在したので, この判 断基準は使わないのと同じであった。しかしこの問題 については, 帯域フィルタないし微分フィルタに関す る本質的な考察が必要となるので以上にとどめる。

（3）エッジの強調一一画像質の改善のためエッジの強 調はよく行われる。また人間の目によるマッチングでむエ ッジの対応を利用していることが主張されている。そこで エッジを強調した画像がどの程度マッチングに有効である かを調べた。エッジ強調画像を式(6)の $G(m, n)$ を使っ て, 各段階の縮約したパッチに対し次式で定義する。

$$
G^{\prime}(m, n)=D(m, n)-\lambda G(m, n) \cdots
$$

入は啇当な定数であり強調の程度に上って変える。

(4) 相関係数による迷走の発見とフィードバックー 通常マッチング精度を検查するのに使われる相関係 数が迷走の判断に使えれば次の様なフィードバック系 が考えられる。迷走の起こりにくい第 1 段階はそのま ま実行し，第 2 , 第 3 段階ではくり返し相関の途中で 最大相関点 $\rho_{\max }$ がある閾值 $\rho_{T}$ より小さくなれば $x-$ 視差の值をその段階の初期值にもどす。

\section{4. 実験と考察}

\section{$4-1$ 資料}

ここで使う資料 ${ }^{11)}$ は, $1: 25,000$ の写真対を $50 \mu \mathrm{m}$ 間隔にサンプリングして, $0-3 D$ の濃度值を 8 ビッ

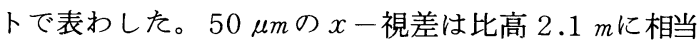
する。対地標足の結果では基準点残差の平均 2 乗誤差 は平面位置 $\pm 1.68 \mathrm{~m}$ (14 点), 標高 $\pm 0.8 \mathrm{~m}$ (13点) 
であった。

偏位修正後の画像対には \pm 1 画素程度の $y$-視差が 残存していた。これはサンプリング時のフィルム歪に 起因寸る。 $x, y$ 方向それぞれ 1 画素の歪があるとす ると, これによって起きうる標高誤差は, 上く知られ た $x$ 一視差と比高の関倸式から,

$$
\begin{aligned}
& \Delta H=\frac{H}{b} \Delta(u-x) \leqq \frac{H}{b}(|\Delta u|+|\Delta x|) \\
& =4.6 \mathrm{~m}
\end{aligned}
$$

と評価される。ここで, b ; 写真上の撮影基線長 ( 87 $\mathrm{mm}), H$; 撮影対地高度 $(3,800 \mathrm{~m}), x, u$; 左右の写 真座標の横軸, $\Delta u, \Delta x$ : 写真座標の誤差。

マッチング結果の精度を評価するため, 新たに写真 から等高線を図化した。図化では, 通常のように地上 標高を追ったものと樹高を描いたものを 2 種類作成し た。これは実験に使った写真の樹木の密集地では, そ の 1 本 1 本は分離されず, マッチングは樹木の頂点部 でなされると考えられるためである。等高線間隔は上 記の標高誤差を考慮して 10 mで描いた。罒ー4，5， 6 に, 左写真の図化領域と, 等高線図を示した。図

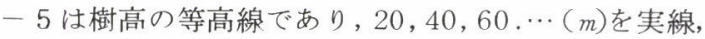
中間を破線で描いた。図一 6 は地上高の等高線であり, $20,40,60, \cdots(m)$ を太線, $10,30,50, \cdots(m)$ を細 線で描いた。さらに樹木のための地上が見えない部分 を破線で書き込んだ。図は 1：10,000で描いたもの を約 $2 / 3$ に縮めている。図化領域は約 $800 \times 1,200 \mathrm{~m}$ であって, 山地部は隠蔽部分はほとんどなく, 均質で 白色雑音に近い濃度分布を示すところが多く迷走が起

\section{こり易い。}

マッチング結果を検照するために 1 つのパッチを選

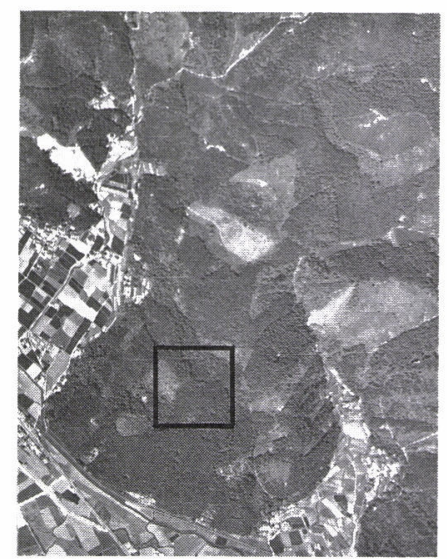

図-4 図化領域の左写真

(約 $1,000 \mathrm{~m} \times 1,200 \mathrm{~m} ， わ く は$ パッチA 示す)
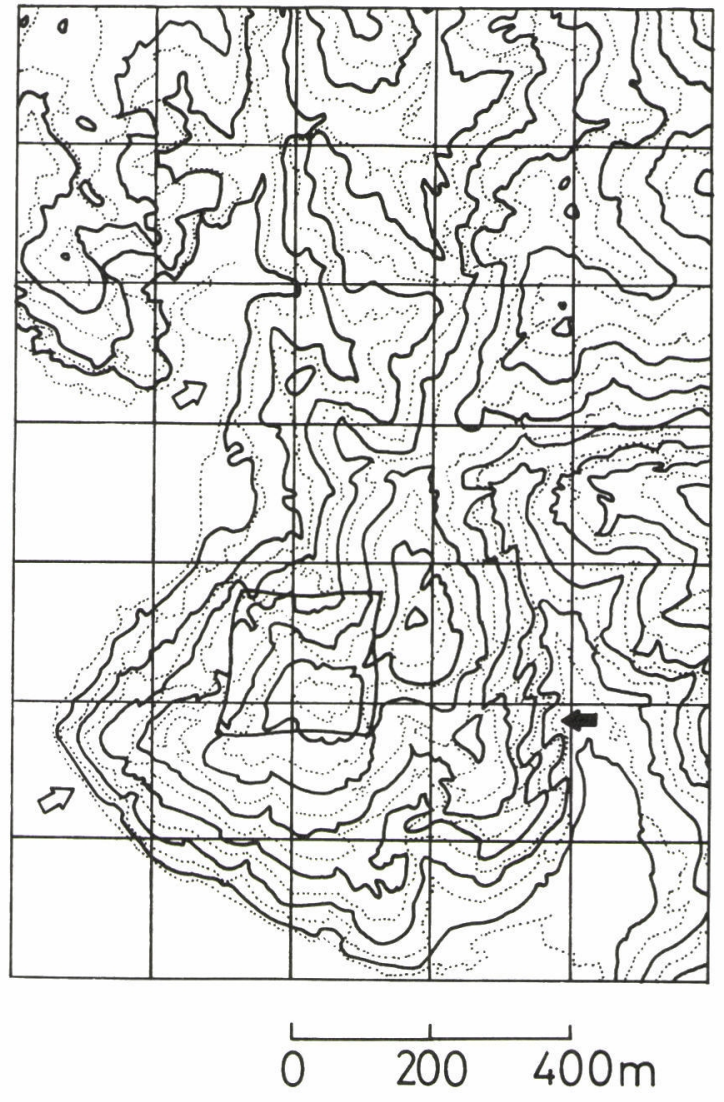

図-5 樹上等高線

(パッチAをわくで囲った)

びその位置を図ー4,5に示し,これをパッチ $\mathrm{A}$ と呼ぶ。 図一 5 のパッチAは, 投影の関係で正方形にならない。 パッチAは比較的テクスチャの乏しい山林部と, 豊富 な伐採地の部分が混在する。樹木は密集していて, 目 視でやっと地表が観測できる程度である。

この論文では, 各対応点のマッチング精度を画素単 位で検照することはせず等高線同士を比較するにとど めた。これは次の理由による。

・実験にイメージディスプレイが使えず, 画像の出力 は寸べてラインプリンタで行った。このため解像度が 低く, 対応画素を厳密に決定することができなかった。

・面積相関は点の対応でなく, 本質的に面の対応であ って, 高い精度が望めない。

- 画像の残存 $y$ 一視差が大きく, 精度を落としている。 4-2 基本的なマッチングの実験

(1) 準備一図化領域は $4 \times 6$ 個のパッチが覆う。 1 つのパッチで図化に用いる格子点は $20 \times 20$ 点である ので図化領域には $80 \times 120$ 点の格子点が含まれる。 


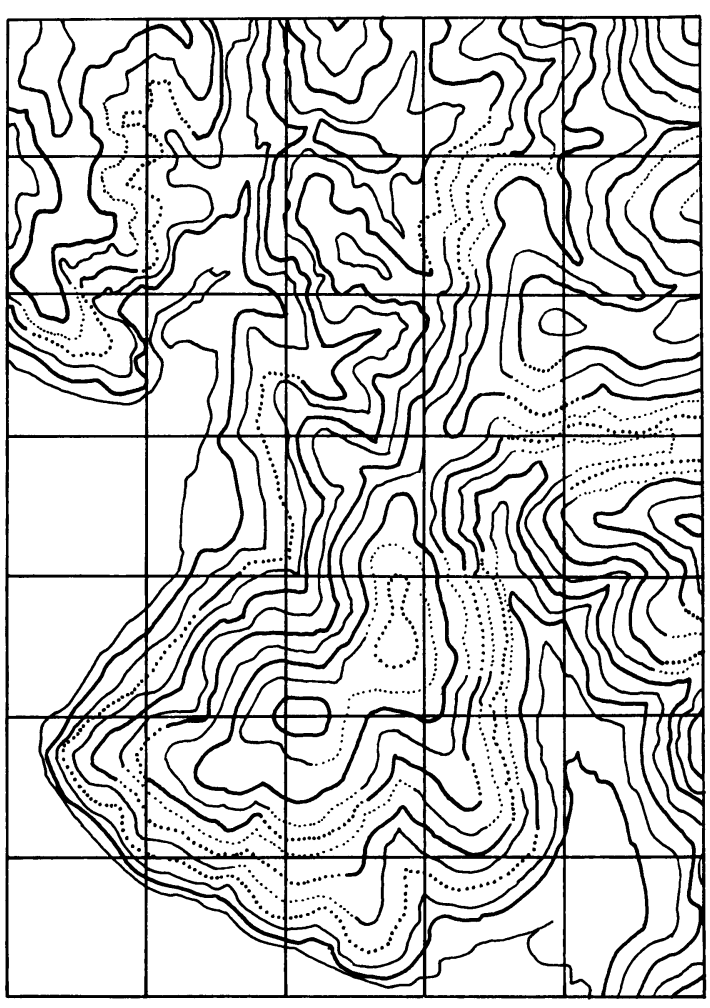

図一 6 地上等高線

1 つのパッチの図化に使う領域は地上約 $200 \mathrm{~m} \times$ $200 \mathrm{~m}$ であり, その中に生ずる最大比高 $\Delta H$ は約 100 $\mathrm{m}$ であるので, パッチ内の最大 $x$ 一視差々 $\Delta p x$ は

$$
\Delta p x=\frac{b}{H} \Delta H=2.3 \mathrm{~mm}=46 \text { 画素 (Io 上) }
$$

である。したがって第 1 段階の最初には，縮約した画 像で \pm 7 画素 $(K=15)$ ，すなわち縮約しない画像上 では，53画素とった。

(2) マッチング結果—パッチごとの相関法が有効で あるかを見るため，相関空の幅を $\ell=15$ ，探索幅を $K$ $=7$ として実行した。最初格子点の整合性を考虑しな かったところ, 対応点の位置の逆転が起こり処理は中 断した。これを考虑して実行した結果が図一7である。 格子点は 1：10,000 図上約 $1 \mathrm{~mm}$ 間隔で配置される。 等高線は格子点のつくる四角形内を線型内挿して描画 した。各段階のくり返し相関の回数は 5 回としたが実 際には 3 回程度で収束し, 4 回目と 5 回目の $x$ 一視差 の最大変動量は各パッチとも2 画素以内であった。

図一 5,6 の等高線図と比較してみると, お打むね, 樹高に近いところを追っていて，比較的良好な結果が

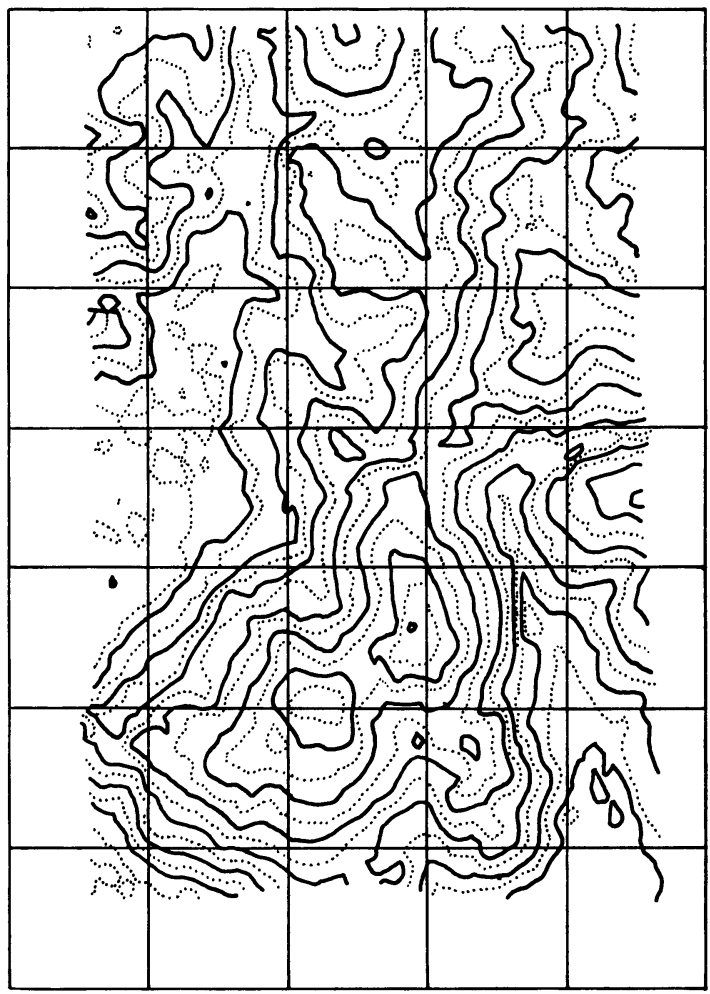

図ー $7 \quad \ell=15$ の相関空による描画

得られている。図の右下方の急勾配部分（図一 5 の黒 い矢印）では両者の中間部を描いている。この部分は のこぎりの歯のように伐採あとがあるが，このマッチ ング法ではするどい等高線の変化に追随できず平均的 な高さとなっている。小さな迷走が左下隅および平地 部 (図一 5 の白い矢印) に見られるが，平地部分の迷 走は標高値としては, $2 \mathrm{~m}$ 以内 ( 1 画素内の $x$-視差) の小さなものである。

マッチングの精度を判断するには通常は相関係数が 使われ，最大相関係数 $\rho_{\max }$ がある閾值 $\rho_{T}$ より小さい とき信頼性がないと判断することが多い。図一 7 の実 験結果から相関係数の分布を調べてみると，パッチ $\mathrm{A}$ では各段階の 5 回目のくり返しの時点で図ー 8 のよう であった。第 3 段階の図では全格子点のうち内側の 20 ×20点についての結果である。 $\rho_{\max }$ が1.0を越える ものが少数あったがこれは計算式（式(5)）が近似式で あることによる。

一般には各段階を追うごとにしだいに雑音が卓越し， 相関係数は小さくなるがこの例では第 3 段階でも比較 的大きい相関倸数を示している。小さい相関係数は散 

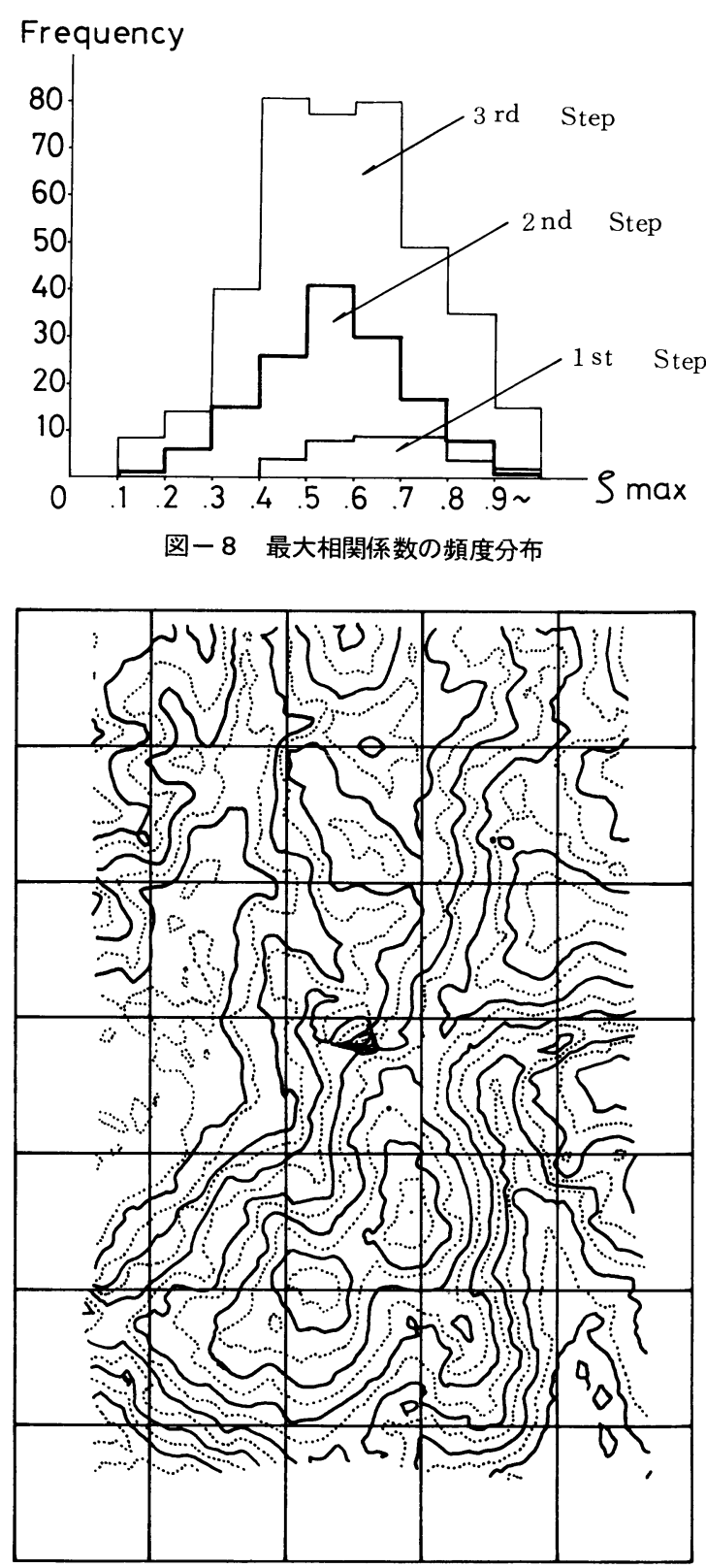

図一 9 探索幅 $K=15$ の場合

乱して現われるが図一 $5,6,7$ の等高線図と相関係数 の値を比較しても, 位置精度との関係は認められなか った。ただ大きな迷走を生こした場合には 0 に近い異 常に小さい值がまとまって現われるのが認められた。 $4-3$ パラメータの比較

（1）探索幅—迷走が起こっても回復するために広い 探索幅をもたせることが考えられる。図ー9は図ー7 と同じ条件で探索幅を全過程通じて $K=15$ とした場合 $-20-$

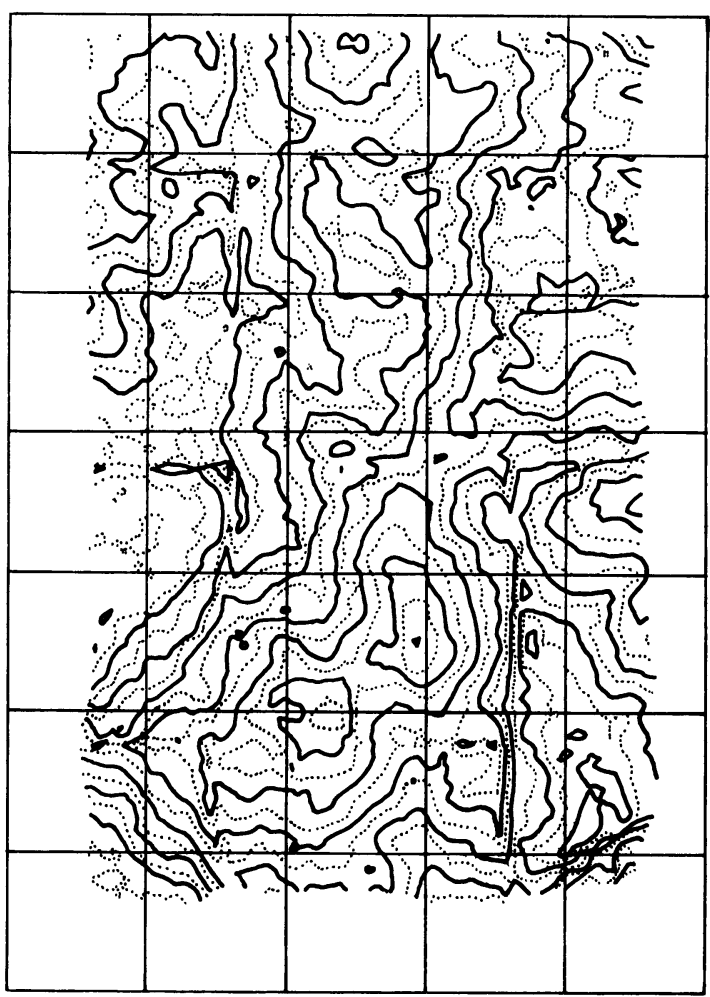

図-10 相関空 $\ell=7$ の場合

である。しかし一部にむしろ新しい迷走が起っている 以外に変化はなかった。

（2）相関空の幅—図ー 7 では 2 つの格子間隔を含む ように $\ell=15$ とした。これ以下では，隣接する相関空 との共通部分がなくなるので, 不安定なマッチングに なることが予想される。図一 10 は $\ell=7$ としたときの マッチング結果であるが, 多くの点で迷走が起ってい るのがわかる。しかし 3 オクターブしか含まない相関 空でも全くのでたらめの結果を与えておらす, 多数の 格子点間の整合性を考虑したマッチングが有効である ことを示している。

逆に相関空の幅を拡げ, $x$ 方向 $l x=31$ とし, $y$ 方向 は位相がそろっているので小さく $\ell y=7$ としとき(す なわち図ー7の場合と面積はほぼ同じ）のマッチング 結果を図-11に示した。相関突を $x$ 軸方向に 2 倍の拡 大をしたにも拘らず解像力の低下はわずかしか見られ ないのが注目される。いいかえると, 探索空を小さく してもここで述べた面積相関法ではそれに応じた解像 力を得ることは期待できないと言え, 安定性の点でや や大きい相関空の方がむしろ望ましいと考えられる。 


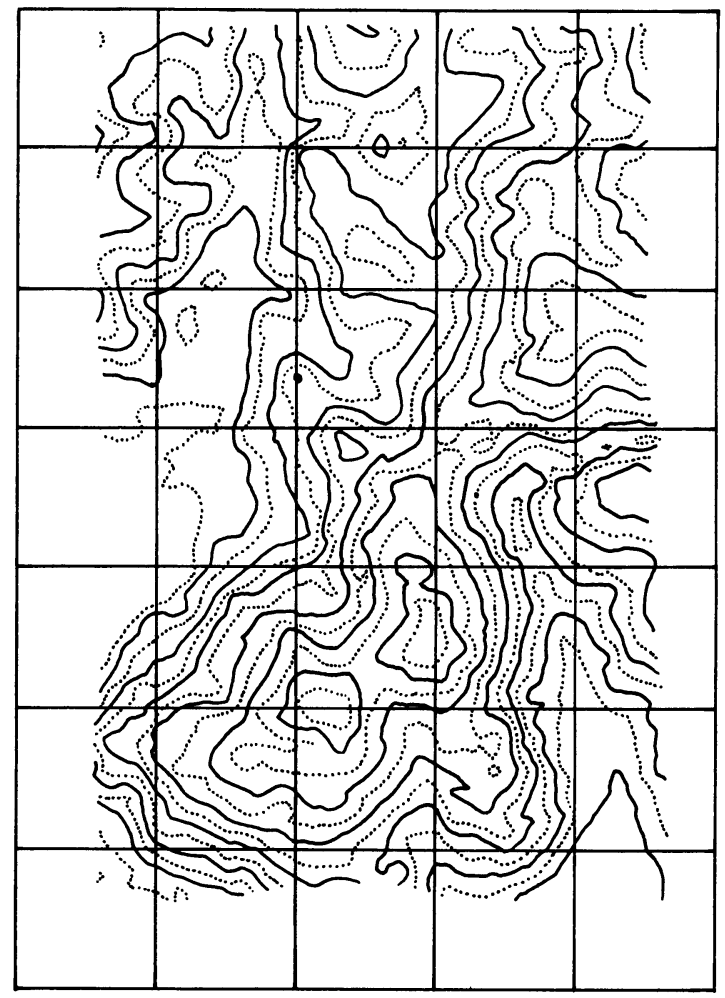

図-11 相関空 $\ell_{x}=31, \ell_{y}=7$ の場合

4-4 エッジ強調の効果

画像のエッジを強諯することでマッチングが改善さ れるかを見るため式(8)で $\lambda=1$ として（他の条件は図 ー 7 の場合と同じ）試みたところ, 図一 7 とほとんど 同じ画像が得られた。ただ広い探索範囲 $(K=15)$ を 与えても図一 9 のような迷走は現われず, 適当なエッ ジ強調は安定性の面で有効のようである。入を極端に

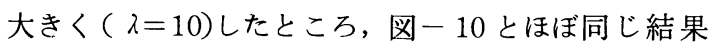
を得た。これは高周波部分しか利用しないことになって 小さな相関空をとるのと同じ効果になったためであ る。

\section{$4-5$ 相関係数による迷走判断の試み}

結論的に言えばこの方法は全く有効でなかった。図 -12 に $\rho_{T}=0.1$ とし, 他は図 -7 と同じ条件で実行 したときの結果を示した。多くの筒所で劣化が起こっ ている。相関空の大きさ，探索範囲， $\rho_{T}$ を変えて実験 したところも同様であり改善は見られなかった。これ はパッチ単位ごとのくり返し相関法が個々の点でマッチ ングを行うというよりは，パッチ全体でマッチングし ているからであって, 個々の $x$ 一視差の值を周囲と独

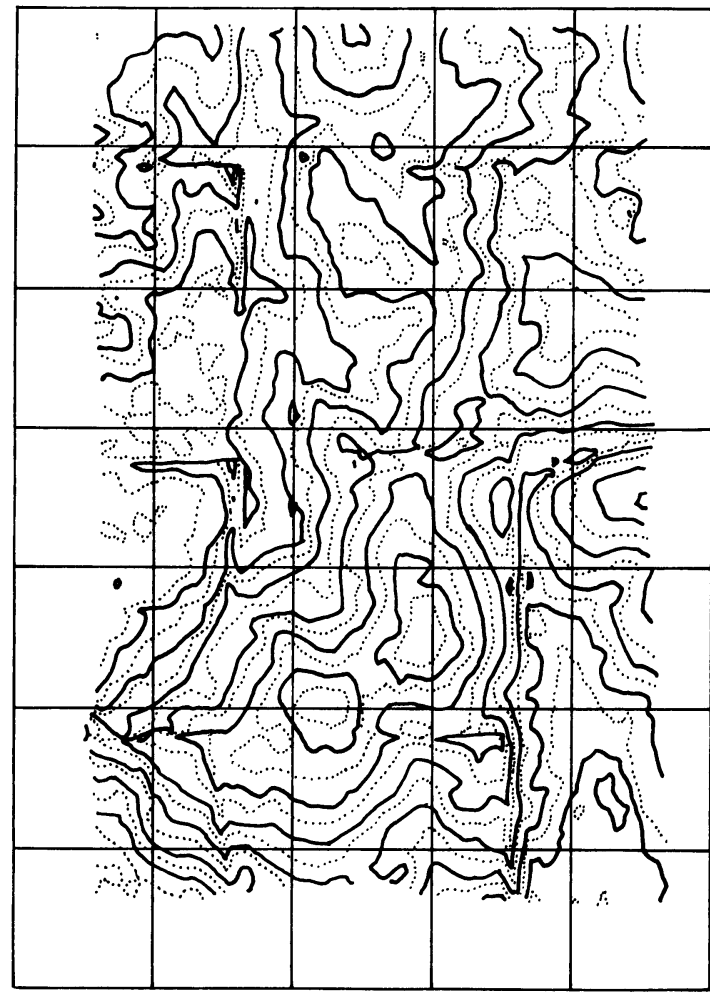

図ー12 相関係数によるフィードバックを行った場合 $\left(\rho_{\max }<0.1\right)$

立に変更するには, 相関係数よりもっと確度のある信 頼性基準を使う必要がある。

\section{5. 結 論}

この論文では多数の格子点を配置したパッチ単位で マッチングを実行する方法が小さな相関空でも迷走を 防ぎ，比較的精度良いマッチング結果を与えることを 示した。マッチングは低周波域の粗いマッチングから 高周波域の細かなマッチングまで帯域を 1 オクターブ ずつずらして 3 段階で行う。この間，画像の位相歪は くり返し相関の過程で消去する。迷走の防止には対応 点間の位置の整合性を配慮するのが効果的であり，画 像のエッジを多少強調するのが安定性の面で効果が見 られた。

しかしこの方法は大縮尺のデジタル画像を対象とす るときには充分でない。それは隠蔽部の解決策を全く 含んでいないことである。このためには画像のエッジ

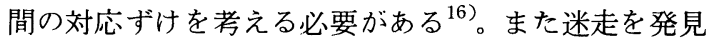
し，再度マッチングを行うフィードバック系を入れる 
ことにも成功していない。ここでは相関倸数による迷 走の発見を試みたがうまく機能しなかった。

\section{参 考 文 献}

1) Marr, D. and T. Poggio; A Computational Theory of Human Stereo Vision, Proceedings of the Royal Society of London, Biological Science 204, pp. $301-$ 328 (1979)

2) Marr, D. and E. Hildreth; Theory of edge detection, Proceedings of the Royal Society of London, Biological Science 207, pp. 187-217 (1980)

3) Marr, D. and T. Pogio; A Theory of Human Stereo Vision, A. I. Memo No. 451, MIT Artificial Intelligence Lob., 1977

4) Grimson, W. E. L.; A Computer Inprementation of a Theory of Human Stereo Vision, A. I. Memo No. 565, MIT AIL, 1980

5). 森 忠次, 服部 進, 今井啓介, 小川一郎; 画像相関を 使った空中写真からの等高線自動図化の一方法一処理手法 と自動標定, 写真測量とリモートセンシング, Vol. 20 , № 4,1981, pp. $4-13$

6) 森 忠次, 服部 進, 内田 修, 田辺広志; 画像相関を 使った空中写真からの等高線自動図化の一方法一偏位修正 と標高ファイルの作成, 写真測量とリモートセンシング, Vol. 21, №2,pp. 4-14

7) Konecny, G. and I Page: Correlation Techniques and Devices, Photogrammetric Engineering and Re- mote Sensing, Vol. 47, No. 3, 1981, pp. 323-333

8) Panton, D. J.; A Flexible Approach to Digital Stereo Mapping, Photogrammetric Engineering and Remote Sensing, Vol. 47, No. 3, 1981, pp. 323-333

9) Mori C., S. Hattori and S. Hamate; Off-Line Stereo Plotting by Means of Image Correlation, Memoirs of the School of Engineering, Okayama University, Vol. 17, No. 1, 1983, pp. 41-60

10) 森 忠次, 服部 進 ; くり返し相関によるステレオマッ チング, 日本写真測量学会昭和 59 年度年次学術講演会発 表論文集, pp. $43-48$

11) 森 忠次, 服部 進, 内田 修; 面積相関法による空中 写真のステレオマッチングの改善, 土木学会論文報告集, 投稿中。

12) Kelly, R. E. and P. R. H. McConnell; The Gestalt Photomapping System, Photogrammetric Engineering \& Remote Sensing, 1977, pp. 1407-1417

13) Oppenheim, A. V. and R. W. Schafer; Digital Processing, Prentice-Hall, pp. 237-249

14) Papoulis, A.; The Fourier Integral and Its Application, Electronic Science Series, McGraw-Hill, 1962, pp. $50-52$

15) 森 忠次, 服部 進, 内田 修; 投影歪による画像相関 の低下に関するスペクトル的考察，写真測量とリモートセ ンシング, Vol . 22, № 4, 1983, pp. 33-39

16）大田友一, 金出武雄 ; 走查線間の整合性を考虑した動的 計画法による対応点探索, 情報処理学会コンピュータビジ ヨン研究会資料 29,1984 